\title{
Władysław Dudziak, Wspomnienia z lat 1945-1948
}

opracowanie:

\section{RYSZARD TOMKIEWICZ}

Ośrodek Badań Naukowych w Olsztynie

(iD) https://orcid.org/0000-0003-3346-0532

DOI: https://doi.org/10.26774/rzz.231

$02 / 2018$

\section{ROCZNIK}

\section{ZIEM}

\section{ZACHODNICH}

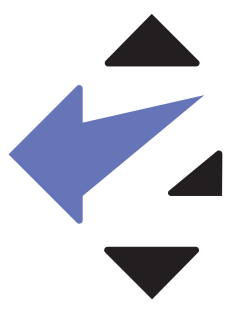


W okresie powojennym w Olsztynie kilkakrotnie organizowano konkursy na wspomnienia nawiązujące do życia i pracy na Warmii i Mazurach w Polsce Ludowej. Prezentowaną relację ks. Władysław Dudziak zgłosił na konkurs zatytułowany Moje XXX-lecie na Warmii i Mazurach, zorganizowany w 1974 r. przez redakcję pisma „Słowo na Warmii i Mazurach" (był to lokalny dodatek „Słowa Powszechnego") oraz Oddział Wojewódzki „PAX” w Olsztynie ${ }^{1}$.

W połowie lat 80. fragmenty swojej relacji ks. W. Dudziak przesłał też na konkurs zorganizowany przez Kurię Biskupią Diecezji Warmińskiej, którego motywem przewodnim były wspomnienia z początków powojennego Kościoła na Warmii, Mazurach i Powiślu. Część z tego materiału została zamieszczona w 1986 r. w „Posłańcu Warmińskim”, dwutygodniku katolickim Kurii Metropolitalnej Archidiecezji Warmińskiej. Materiał podzielono na dwie części, opatrzone osobnymi tytułami (Pierwsze miesiqce po wojnie ${ }^{2}$ i Rok $1946^{3}$ ). W części pierwszej odnotowano dwie ingerencje cenzury (dotyczące trzech tematów), natomiast w części drugiej oznaczeń takich nie odnotowano.

Pierwsza z ingerencji dotyczyła kwestii narodowościowych w powojennych realiach Mazur, a mianowicie unikania przez ludność autochtoniczną przymusowej polonizacji. Pominięto też fragment o osadnictwie ludności wiejskiej z Mazowsza, która - jak zapamiętał i zapisał ks. Dudziak - najczęściej osadzała się na Mazurach tymczasowo, „z myślą o zdobyciu środków na odbudowę zniszczonych rodzinnych gospodarstw"

Druga ingerencja cenzury w „Posłańcu Warmińskim” dotyczyła relacji ks. Dudziaka na temat odzyskania monstrancji, która w czasie wojny była ukryta w jednym z mieszkań w Mrągowie. Relacja urywa się w miejscu, gdy ks. Dudziak opisał wizytę w tym domu („Niewiasta, która w tym mieszkaniu była, powiedziała, że zabrali $\left.[\ldots]^{\prime \prime}\right)^{5}$.

Po siedmiu latach ponownie część relacji, nieżyjącego już wówczas ks. W. Dudziaka, została opublikowana. Tym razem w książce Kazimierza Sopucha (profesora socjologii, nauczyciela akademickiego, także literata i dziennikarza), która ukazała się w 1993 r. dzięki staraniom Ostrołęckiego Towarzystwa Naukowego im. Adama Chętnika ${ }^{6}$. Była to publikacja szczególna, odnosząca się do sytuacji na pograniczu mazursko-kurpiowskim i sytuacji ludności mazurskiej po 1945 r. Przeważającą jej część stanowił siedmiorozdziałowy materiał, będący poprawioną i uzupełnioną wersją pracy magisterskiej

Konkurs Moje XXX-lecie, „Słowo na Warmii i Mazurach”, nr 15 (1974), s. 1.

W. Dudziak, Rok 1946, „Posłaniec Warmiński”, nr 19 (1986), s. 3, 5. 
Kazimierza Sopucha, powstałej w drugiej połowie lat 50., a zatytułowanej: Kształtowanie się świadomości narodowej Mazurów w okresie 1945-1957. Reszta (ok. 1/4 objętości) to fragmenty wspomnień ks. Władysława Dudziaka, prywatnie wuja Kazimierza Sopucha (ks. W. Dudziak był bratem jego matki). Zostały one uzupełnione przez Kazimierza Sopucha o nieznane wcześniej fakty z życia ks. Władysława Dudziaka, który wielokrotnie opowiadał mu o swoich przeżyciach (pominiętych we wcześniejszych wspomnieniach). Kazimierz Sopuch, jako uczeń mrągowskiego gimnazjum, przez cztery lata (1948-1952) mieszkał u wuja na plebanii

Połączenie w jednej książce rozprawy socjologicznej i wspomnień miało na celu uzupełnienie i ukazanie niejako w praktyce tez zawartych w pracy magisterskiej Kazimierza Sopucha, który zresztą sam o tym nadmienia, pisząc: „połączenie mojej pracy socjologicznej ze wspomnieniami ks. W. Dudziaka uzasadniam także i tym, że moja praca, zawierająca w swej treści wiele z tego, co przeżyłem, posiada w pewnym sensie charakter wspomnień" ${ }^{\prime}$.

Uzasadniając cel powtórnego wydania tego materiału, należy wyraźnie zaznaczyć, że trzy wersje wspomnień ks. Władysława Dudziaka (pierwotna z 1974 r. - przywołana niżej, z 1986 r. - opublikowana w „Posłańcu Warmińskim” i z 1993 r. - zamieszczona w książce Kazimierza Sopucha), choć dotyczą tego samego okresu, zostały znacznie przeredagowane, przy zachowaniu ogólnego przesłania. Przykładem niech będzie jeden z fragmentów zamieszczonych w 1986 r., który brzmiał: „W niedzielę odprawiałem dwie Msze św.: jedną dla Niemców o 9.00 (kilku - kilkunastu), drugą o 10.00 dla Polaków (też nieliczni)" ${ }^{\prime \prime}$, a w wydaniu z 1993 r. tę samą kwestię zapisano: „W mieście odprawiałem tej niedzieli dwie Msze św., jedną dla Niemców z ewangelią po niemiecku o godz. 9, a w godzinę później drugą dla Polaków. Na obu mszach było niezbyt dużo wiernych, jednak na pierwszej więcej"10.

Fragmenty wspomnień ks. W. Dudziaka (dotyczące lat 1945-1946), a przywołane w pracy K. Sopucha, nie zostały opatrzone redakcją naukową stosowaną przy wydawaniu tekstu źródłowego. Prezentowane niżej fragmenty wspomnień ks. Władysława Dudziaka są wersją pierwotną, najstarszą, bez późniejszych ingerencji redaktorów czy wydawców.

Wspomnienia ks. Władysława Dudziaka znajdują się w Zbiorach Specjalnych Ośrodka Badań Naukowych im. Wojciecha Kętrzyńskiego w Olsztynie, gdzie zdeponowane zostały w latach $70 .{ }^{11}$ Oryginał, pisany ręcznie na kartkach formatu A5, liczy 33 strony. W edycji uwspółcześniono zasady ortografii i interpunkcji. Niezbędne wyjaśnienia podano w nawiasach kwadratowych. Ujednolicono czas wspomnień na przeszły. PTH-324,Władysław Dudziak, Wspomnienia z lat 1945-1948, s. 33

K. Sopuch, W. Dudziak, op. cit., s. 5.

Ibidem, s. 6.

W. Dudziak, Pierwsze miesiqce po wojnie, „Posłaniec Warmiński”, nr 18 (1986), s. 6.

Idem, Wspomnienia mragowskiego proboszcza z lat 1945-46, [w:] K. Sopuch, W. Dudziak, op. cit., s. 84. 
Ks. Władysław Dudziak (1910-1987) urodził się we wsi Lipianka (parafia Goworowo) w powiecie ostrołęckim. Był synem Władysława (1868-1945) i Anny (18761961). Miał siostrę Cecylię i dwóch braci: Józefa i Piotra. W czerwcu 1937 r. otrzymał święcenia kapłańskie z rąk ks. abp. Romualda Jałbrzykowskiego (w tym czasie metropolity wileńskiego). W kolejnych latach ks. W. Dudziak sprawował posługę duszpasterską na Wileńszczyźnie, m.in. w Szumsku i Holszanach. Okres wojny spędził w rodzinnej wsi na północnym Mazowszu. Wiosną 1945 r., wraz z jedną z grup przesiedleńców, trafił do Mrągowa; 13 lipca tr. został mianowany proboszczem w parafii św. Wojciecha. Pomagał przy organizacji gimnazjum w tym mieście, gdzie następnie uczył matematyki i religii oraz prowadził internat. Był wizytatorem nauczania religii w powiecie mrągowskim. Zorganizował dom dla Sióstr Misjonarek Świętej Rodziny i kuchnię „Caritas”. Współorganizował dom dziecka. Ks. Dudziak trafił w miejsce szczególne. W Mrągowie oraz na terenie okalającego go powiatu mieszkało szczególnie wielu Mazurów. Ludność ta, zarówno przez przedstawicieli polskiej administracji, jak i osadników, niejednokrotnie traktowana była nieufnie. Wielu uważało ich po prostu za Niemców. Pojednaniu nie sprzyjała „twarda mowa” miejscowych i ich ewangelickie wyznanie ${ }^{12}$.

W Mrągowie proboszczem był do roku 1960. Potem został przeniesiony do parafii św. Jerzego w Kętrzynie. Zmarł w styczniu 1987 r. Pochowany został na cmentarzu w Mrągowie ${ }^{13}$. W kościele, gdzie pełnił posługę, umieszczona została tablica pamiątkowa o treści: „Śp. Ks. Kanonikowi Władysławowi Dudziakowi 1910-1987, pierwszemu proboszczowi parafii Mrągowo, gorliwemu duszpasterzowi, wychowawcy młodzieży - Wychowankowie. Bóg sprawuje wszystko we wszystkich”.

$$
\text { 冰决况 }
$$

Prezentowane wspomnienia ks. Władysława Dudziaka nie są jedynie relacją na temat życia religijnego w powojennym Mrągowie, ale to przede wszystkim dokument ukazujący powojenne życie w niewielkim miasteczku na Mazurach, widziane przez księdza katolickiego.

Spośród wielu materiałów wspomnieniowych przechowywanych w Ośrodku Badań Naukowych w Olsztynie ten wyróżnia się, gdyż próżno w nim szukać - jakże wówczas powszechnych we wspomnieniach wysyłanych na konkursy - elementów gloryfikujących powojenny ustrój, przemiany polityczne, gospodarcze i społeczne. Pisząc o życiu parafii i miasta, autor odtwarza ówczesną codzienność, problemy dotykające mieszkańców, sposoby ich przezwyciężania. We wspomnieniach ks. Dudziaka dominuje optymizm i wiara w odbudowę życia społecznego.

W kilku miejscach wspomnień, tam, gdzie odnoszą się one do sytuacji ludności autochtonicznej deklarującej przynależność do narodu polskiego, relacji osadników 
z Niemcami czy utożsamiania przez osadników Mazurów z Niemcami, autor wspomnień, nie mając dostatecznej wiedzy, stosuje daleko idące uproszczenia, w jakimś stopniu wynikające z zabiegów propagandowych przez lata utrwalanych.

\section{[Wspomnienia]}

W styczniu 1945 r. przestały wzywać wiernych do modlitwy dzwony kościoła parafialnego w Ządzborku ${ }^{14}$. Po upływie pół roku, 15 lipca w niedzielę, o godzinie 10, rozpoczęły od nowa swoją służbę, wzywając wiernych na Mszę świętą. Tego dnia właśnie przybyłem z osadnikami od Myszyńca, dokąd przybyłem 13 lipca z Lipianki, gm. Goworowo, powiat Ostrołęka, gdzie z rodziną spędziłem czas okupacji. Parafia pod wezwaniem św. Wojciecha w Sensburgu liczyła przed wojną ponad 2 tys. [osób]. Pracowało w niej 2 kapłanów i 2 siostry zakonne, ze zgromadzenia sióstr Katarzynek. Miała parafia kościół i dom kaplicę w Mikołajkach, plebanię i dwa domy: dom św. Wojciecha i dom czynszowy, krótko przed wojną zabrany ${ }^{15}$.

W chwili mojego przybycia kapłana nie było żadnego ani sióstr. Dom parafialny był wypalony, plebania bez okien, wewnątrz zniszczona. Kościół miał postrzelaną pociskami z artylerii wieżę i dach. Dachówki otrząśnięte z wieży [i] z 1/10 dachu kościelnego. Wewnątrz był mało zniszczony, tylko ogołocony ze wszystkiego co przedstawiało jakąś wartość i dało się wynieść z kościoła. Ilu pozostało wiernych, trudno było ustalić.

Ludność Ządzborka była przeważnie protestancka. W 1944 r. jesienią przesiedlono na teren powiatu mieszkańców powiatów wschodnich. Zamożniejsi uciekli w styczniu [1945 r.] przed zbliżającymi się wojskami radzieckimi. Biedota i średniacy pozostali. Mężczyźni byli w wojsku, więc przeważali starcy, dzieci i kobiety. W październiku tego roku starostwo w Ządzborku sporządziło spis i wtedy na terenie powiatu mieszkało 38 tys. Niemców, 400 Polaków i Mazurów ${ }^{16}$.

Spis ten nie odpowiadał rzeczywistości. Mazurzy bowiem uważali się za Niemców i trudno im się dziwić. Gdy szli na te ziemie, nie mieli świadomości narodowej,

14 Żołnierze Armii Czerwonej zdobyli Sensburg (w niektórych dokumentach widniała nazwa: Segensburg) w nocy z 27 na 28 I 1945 r. Zarówno pierwsi polscy osadnicy, jak i przedstawiciele polskiej administracji zwali miasto Ządzborkiem (lub Ządźborkiem). Ostatecznie powołana w styczniu 1946 r. przy Ministerstwie Administracji Publiczne Komisja Ustalania Nazw Miejscowych i Obiektów Fizjograficznych, nadała miastu nazwę Mrągowo (decyzje w sprawie nazw nawiązujących do nazwisk osób związanych z terenem Warmii i Mazur nie były odosobnione. Kierując się tą zasadą - prócz Mrągowa - tego typu nazwe otrzymało też Giżycko, Kętrzyn i Pieniężno). W przypadku Mragowa chciano w ten sposób uczcić pamięć o Krzysztofie Celestynie Mrongowiuszu (1764-1855), duchownym ewangelickim, językoznawcy, edytorze i filozofie, z miasteczkiem tym jednak w żaden sposób niezwiązanym. W prezentowanych wspomnieniach, ks. W. Dudziak kilkakrotnie zamiennie używa nazw miasta; R. Tomkiewicz, Mragowo w latach 1945-1947, „Mrągowskie Studia Humanistyczne”, nr 1 (1999), s. 69.

16 Wg danych z początku lipca 1945 r. w mieście żyło 3200 Niemców i Mazurów (dane łączne) i tylko 113 polskich osadników (w całym powiecie, według jego danych, mieszkało 26320 osób, w wiekszości Niemców i Mazurów i ok. 450 osadników). Na przełomie 1945 i 1946 r. Mrągowo liczyło 3369 mieszkańców, w tym 2970 Niemców, 154 Mazurów i 245 Polaków; Ośrodek Badań Naukowych im. Wojciecha Kętrzyńskiego w Olsztynie, Zbiory Specjalne, sygn. R-25, Wspomnienia Feliksa Guisa, s. 7-8. Por.: H. Murawska Ludność z polskich Kresów Wschodnich w powiecie mrqgowskim, „Mrągowskie Studia Humanistyczne”, nr 1 (1999), s. 89-102; A. Sakson, op. cit., s. 100-105. 
bo w tym czasie chłop w centralnej Polsce też jej nie posiadał. Jako przykład niech posłuży mieszkaniec wsi Wierkowo - Chrzanowski. Pamiętał, że ojciec jego przeniósł się na Mazury z ciechanowskiego i to, że był szlachcicem. Szlachta miała większe poczucie narodowe. Tego właśnie Chrzanowskiego z trudem udało mi się nakłonić, by wpisał się na listę mazurską ${ }^{17}$.

Ilu w tej masie 38 tys. było katolików, niemożliwością było ustalić. Dużo uciekło przed frontem, szczególnie z miasta, a z wiosek część wyjechała w tym czasie, gdy opuszczał teren Polski wikary ks. Ernest ${ }^{18}$.

Pierwszą Mszę św. odprawiłem 15 lipca [1945 r.]. Była na niej garstka niewiast i kilku Polaków. Następnej niedzieli odprawiłem [mszę] o 9 godzinie dla Niemców z przeczytaną ewangelią w języku niemieckim i o godzinie 10 dla Polaków. Nie wyobrażałem sobie mszy św. niedzielnej bez gry organów. Organy ocalały, gdyż w kościele wojska radzieckie wyświetlały filmy, podczas których pewien oficer grał na organach. Zapewne temu oficerowi zawdzięcza parafia, że organy nie zostały zniszczone.

Wskazano mi nauczyciela Thomasa, który umiał grać na organach. Był on protestantem, ale zgodził się za opłatą grać podczas nabożeństw. Na mszy dla Niemców podsunięto mu nuty pieśni, które zwykle śpiewano, i zebrani w kościele wierni śpiewali je w języku niemieckim. Po podniesieniu zaśpiewali pieśń do Matki Boskiej na nutę Serdeczna Matko. Przyszło już kilku Polaków, usłyszawszy melodię znajoma, a słowa pieśni niemieckie włączyli się ze śpiewem Boże coś Polskę.

Odprawiałem w ten sposób [msze] do powrotu dawnego wikarego i sióstr Katarzynek. W dni powszednie miałem na mszy św. kilka niewiast [spośród] miejscowej ludności. Polacy przychodzili tylko w niedzielę i to bardzo mało, bo w mieście i na wsi było [ich] niewielu i nie wszyscy byli wierzącymi. Aby w kościele było więcej osób, zastępca komendanta milicji przyprowadzał milicjantów ${ }^{19}$ i zostawiał ich w przejściu dość luźno, by robiło wrażenie, że kościół jest zapełniony. Z chwilą powrotu ks. Woelkiego, łączność moja z miejscowymi katolikami przerwała się.

W dzień powszedni nie miałem nikogo na mszy św., oprócz ministranta - syna kościelnej. Mieszkałem u kościelnej, gdyż plebania nie nadawała się na razie do mieszkania. Żywiła mnie stołówka starostwa. W mieście nie było na razie żadnego sklepu $^{20}$. Nic kupić nie było można. Całe moje szczęście, że byłem niepalący.

17 Autor zasygnalizował tu tylko skomplikowaną kwestię poczucia tożsamości narodowej wśród Mazurów, w kontekście zbliżającej się weryfikacji narodowościowej i prób repolonizacji tej ludności.

18 Ks. Ernst Woelki (1913-2008), był ostatnim niemieckim proboszczem w Mrągowie. Do Niemiec wyjechał w październiku 1945 r. zob.: A. Kopiczko, op. cit., s. 70-71.

19 Początkowo nikogo nie dziwiło uczestnictwo w mszach św. zwartych grup żołnierzy i milicjantów, jak to miało miejsce w Mrągowie.

20 Podobnie jak w innych miastach, tu także początkowo handlowano wprost na ulicach i spontanicznie zorganizowanym targowisku. W lipcu lub w sierpniu $1945 \mathrm{r}$. zawiązano spółdzielnię spożywców „Grunwald”. Pół roku później było już ok. 35 prywatnych placówek handlowo-usługowych. Wobec panującego niedostatku, stosunkowo w najlepszej sytuacji były osoby zatrudnione na etacie w organizujących się urzędach i większych przedsiębiorstwach, których pracownicy mieli na ogół zagwarantowaną aprowizację. Najważniejsze urzędy (np. starostwa lub urzędy miejskie) prowadziły także własne stołówki. Czasem jak w przypadku Mrągowa, mogły z nich korzystać również osoby niezatrudnione w urzędzie; R. Tomkiewicz, op. cit., s. 80-82. 
Magistrat posiadał robotników, którzy wykonywali nakazane im prace. Ponieważ nie miałem pieniędzy, zwróciłem się do starosty ${ }^{21}$, by mi przydzielono kilka niewiast do uprzątnięcia śmieci z plebani. Szklarz oszklił okna, chociaż połówkami [szyb] i tylko ramy zewnętrzne. Znalazłem też ślusarza, który dorobił mi klucze. Wcześniej już zaraz po sprzątnięciu plebanii przeniosłem się od kościelnej i zamieszkałem mimo braku szyb w oknach.

Po zamieszkaniu trzeba było pomyśleć o kościele. Przez dziury w dachu i na wieży lała się woda podczas deszczu. Przydzieleni przez magistrat ludzie (autochtoni) uzupełnili brakujące dachówki na kościele i wieży, łatając deskami dziury w dachu wybite kulami. Już jesienią [1945 r.] oszkliłem wybite szyby w kościele. Resztę roboty zostawiłem na przyszłe lata, gdy będą wierni, więc również i ofiary. Przez pierwszy miesiąc nikt nie zwracał się o posługę, nie licząc chrztu z wody spod Mikołajek. Na razie bowiem nie miałem olejów. Oleje otrzymałem z Olsztyna. Z Myszyńca otrzymałem starą komżęe2.

W sierpniu pod koniec miesiąca miałem pierwszy chrzest i ślub. Otrzymałem wtedy od świadka 100 zł, a młodzi, Polacy z Wileńszczyzny, którzy w Niemczech połączyli się, zaprosili na ucztę weselną. Byli na tej uczcie prawie wszyscy Polacy z miasta.

Pierwsza chora, którą w tym miesiącu zaopatrzyłem sakramentami i którą w parę dni [później] pochowałem, była Niemką, mieszkającą pod miastem. Mąż zmarłej przyniósł mi kilkanaście gruszek. Za posługę brałem dobrowolne ofiary, a od autochtonów nie otrzymywałem nic. Początkowo posiadali oni konie i krowy. Później skradziono im [je], a resztę tym, którzy nie podpisali listy mazurskiej, cały dobytek skonfiskowano. Rozpowszechniło się złodziejstwo. Niestety, procederem tym zajmowali się nieraz przedstawiciele władzy, sołtysi, wójtowie, milicjanci, a nawet starostowie. Nakaz podpisania listy mazurskiej, złodziejstwo i szaber, bezprawie, bałagan i kłótnie międzypartyjne wśród Polaków, wyrządzały wiele szkody Polsce. Z wielu ludzi uczyniło to dopiero Niemców, gdy przedtem czuli swą od Niemców odrębność, nie mając co prawda poczucia przynależności do narodu polskiego. Polsce nie pomogło to, że za kilka lat wielu szabrowników i złodziei poszło za kratki.

Jadąc na Mazury, miałem i trochę złota, bransoletę, łańcuszek i dwa medaliki. Za bransoletę później od wójta z Sorkwit ${ }^{23}$ kupiłem krowę, za łańcuszek i medaliki - kanapę i fotel. Krowa była zapewne z tych, co skonfiskowano tak zwanym Niemcom, kanapka i fotel zapewne zabrane kierownikowi szkoły niemieckiej [w Sorkwitach], którą wójt obrał sobie za siedzibę. Te dwa tysiące [?] szybko się rozeszły. Stanęła przede mną alternatywa powrotu skąd przyjechałem, albo głodówka. Zwierzyłem się z myśli opuszczenia Ządzborka urzędnikom starostwa, z którymi żyłem w przyjaźni. Ci wymogli na staroście dotację 1500 zł dla kościoła.

21 Od końca maja 1945 r. starostą powiatu mrągowskiego był Czesław Krzewiński (ur. 1912 r.). Należał do PPR. Pełnił urząd do jesieni 1947 r., por.: R. Tomkiewicz, op. cit., s. 80, 81.

Dalsza część zdania nieczytelna. 
Otrzymywałem to przez dwa miesiące. Od listopada [1945 r.] usamodzielniłem się. Kupiłem konia i [drugą ?] krowę i chociaż nadal obfitości nie zaznawałem, ale mogłem już jakoś żyć. Mlekiem dzieliłem się z kościelną, która doiła krowę, i właścicielką Troszczykowa, która udzielała mi koniczyny dla krowy.

W sierpniu [1945 r.] otrzymałem intencję od pani Brudnickiej i zaproszenie do poświęcenia apteki ${ }^{24}$. Na przyjęciu u państwa Brudnickich spotkałem trzech oficerów miejscowej jednostki ze służby zdrowia, którzy poradzili mi, co mam zrobić, by żołnierze brali udział w niedzielnej mszy. Dowódcą był oficer sowiecki, który nosił mundur rosyjski, [natomiast] inni oficerowie sowieccy (również w tej jednostce) nosili mundury polskie. Poradzono mi, bym poszedł do kwatery dowódcy i rozmówił się z nim na temat uczęszczania żołnierzy do kościoła. Załatwiłem również msze świętą dla oddziałów kwaterujących na majątkach. Od tej pory żołnierze na godzinę 9 rano przychodzili na mszę św., jak również dojeżdżałem do Użranek ${ }^{25} \mathrm{i}$ tam odprawiałem [mszę] w świetlicy dla żołnierzy i dla katolików z tej wioski²6.

Starosta na moją prośbę przydzielił kościół w Nawiadach ${ }^{27}$ dla żołnierzy i osadników. W okolicach Piecek i Nawiad było najwięcej osadników. Żołnierze do Nawiad przyszli tylko raz, bowiem stacjonowali o $6 \mathrm{~km}$. Sprawa kościołów leżała mi bardzo na sercu. Już drugiego dnia po swym przybyciu na Mazury, gdy byłem w Olsztynie, omawiałem tę sprawę $\mathrm{w}$ województwie. Obiecano mi połowę, ale dopiero po przesiedleniu Niemców i weryfikacji Mazurów. Wytypowałem kościoły, o które miałem się starać. Nawiady, Piecki, Szestno, Mikołajki i Sorkwity. Nawiady otrzymałem ${ }^{28}$, w Pieckach kościół poświęciłem drugiego [dnia] Świąt Bożego Narodzenia [1945 r.]. W Sorkwitach i okolicy było zbyt mało katolików i już w listopadzie [1945 r.] był tam pastor ewangelicki, ks. Jagucki ${ }^{29}$. O kościół w Szestnie złożyłem podanie do Starostwa, które przesłało

24 Autor pomylił się. Małżeństwo aptekarzy, Heleny i Zbigniewa Brudnickich, przyjechało do Mrągowa dopiero w październiku 1945 r. Burmistrz Feliks Guis zaoferował im mieszkanie i lokal na aptekę (potem nazwaną „Pod Orłem”) z pełnym wyposażeniem i z zapasem leków, toteż zdecydowali się pozostać.

25 Użranki, wieś w powiecie mrągowskim, położona ok. 10 km od Mrągowa i 20 km od Mikołajek. Kościół w stylu neogotyckim wzniesiono u schyłku XIX w. i pierwotnie należał do ewangelików.

26 W okresie, o którym mowa, w pobliżu Mragowa nie stacjonowały wojska polskie. Wiadomo natomiast, że niedaleko, na styku powiatów kętrzyńskiego, reszelskiego i mrągowskiego wojska radzieckie miały poligon artyleryjski, a w istocie stacjonujący tam żołnierze w głównej mierze wykorzystywani byli do penetracji pobliskiej kwatery Hitlera w Gierłoży. Żołnierze ci nie uczestniczyli jednak w mszach św. organizowanych przez ks. W. Dudziaka.

27 Chodzi o Nawiady, wieś w powiecie mrągowskim, w gminie Piecki, gdzie znajduje się dawny kościół ewangelicki, po 1945 r. użytkowany przez katolików, zob.: K. Bielawny, Kościół ewangelicko-augsburski na Warmii i Mazurach po II wojnie światowej w spojrzeniu historyczno-ekumenicznym, Olsztyn 2008 passim.

28 Ks. Władysław Dudziak msze św. w Nawiadach odprawiał w sierpniu 1945 r., zob.: K. Bielawny, Przejmowanie Kościołów ewangelickich przez ludność katolickq na terenie diecezji warmińskiej w latach 19451946, „Forum Teologiczne”, nr 8 (2007), s. 118.

29 Ks. Alfred Jagucki (1914-2004). Pastor ewangelicki, dr teologii. Od 1945 na Mazurach, najpierw w Sorkwitach, potem w Szczytnie. W latach 1959-1963 senior diecezji mazurskiej. Potem przeniesiony do Cieszyna, E. Kruk, Księża Diecezji Mazurskiej Kościoła Ewangelicko-Augsburskiego w Polsce w latach 1945-1950, „Biuletyn Mazurskiego Towarzystwa Ewangelickiego w Olsztynie”, nr 7 (2007), http://diec. mazurska.luteranie.pl/pl/biuletyn/MTE_2007_07_49.htm\#JaguckiA (dostęp: 28 V 2018 r.). 
moje pismo do województwa. Z Olsztyna zażądano wykazu katolików i ewangelików w gminie Szestno. Stosunek był tak niekorzystny dla katolików, że kościoła nie przyznano.

W 1945 r. poza gminą Piecki-Nawiady, na wioskach była znikoma ilość osadników. Nie było więc dla kogo przejmować świątyń poewangelickich. Z drugiej strony, kościoły te w powiecie Ządzborka nie były opuszczone, więc nie można było pozbawiać świątyń autochtonów - ewangelików. Inna rzecz, że wtedy myślałem, że nie będzie pastorów Polaków, gdyż tych hitlerowcy wyniszczyli, a ludność ewangelicka będzie garnęła się do świątyń razem z Polakami. Przed wojną na Wileńszczyźnie prawosławni chętnie brali udział w majowych czy różańcowych nabożeństwach. Myliłem się, o czym się przekonałem później.

W październiku [1945 r.] w samym Mrągowie zaczęto organizować szkołę ${ }^{30}$. Przybył inspektor szkolny pan [Antoni] Piątek ${ }^{31}$ i pan [Zygmunt] Wieliczko, który został kierownikiem szkoły podstawowej ${ }^{32}$. Obaj zwrócili się [do mnie] o pomoc w organizowaniu [szkoły]. Na naukę zgłaszała się tylko dziatwa napływowych Polaków. Autochtoni od szkoły polskiej trzymali się z daleka. Mnie poproszono o zorganizowanie kompletów gimnazjalnych. Zgłosiło się 12 osób tylko do pierwszej klasy. Do nauczania zgłosił się aptekarz mgr [Zbigniew] Brudnicki, pan Sierakowski i ja. Pan Brudnicki uczył przedmiotów przyrodniczych, pan Sierakowski przedmiotów humanistycznych i był wychowawcą klasy. Ja miałem powierzone kierownictwo matematyką i religię.

Jesień i początek zimy dla wielu mieszkańców powiatu były okresem niedożywienia. Wśród autochtonów uznanych za Niemców zaczął szerzyć się tyfus. Mając konia, jeździłem spowiadać. Były naturalnie i pogrzeby. Pomocy materialnej w tym czasie udzielać nie miałem z czego. Naturalnie za posługi nie pobierałem żadnych opłat.

Tak przeszło pół roku pionierskiej pracy dla Boga i Polski. Dewizą moją było pracować dla każdego wierzącego bez różnicy narodowości czy też przekonań politycznych. Nie szukałem zysków materialnych. Moje mieszkanie było chyba najmniej zaopatrzone ze wszystkich mieszkań mieszkańców Ządzborka. Zima 1946 r. była łagodna. Pomogło to łatwiej znosić niedostatek. Co prawda lata wojny spędzane bez pracy parafialnej, a szczególnie zima 1944/1945 przyzwyczaiła mnie do znoszenia biedy.

Z początkiem roku nadeszło pismo z Kurii (tylko tą drogą administrator apostolski dr [Teodor] Bensch ${ }^{33}$ i jego kanclerz [Stanisław] Kobyłecki ${ }^{34}$ kierowali nielicznym duchowieństwem w diecezji), by kościołów ewangelickich samodzielnie nie zajmować,

30 Autor pomylił się. Pierwsza szkoła powszechna w powojennym Mrągowie rozpoczęła działalność tradycyjnie, tj. 1 września, a organizację tej placówki rozpoczęto 27 VII 1945 r., wraz z wręczeniem nominacji dla pierwszego dyrektora.

31 Antoni Piątek był inspektorem szkolnym w powiecie mrągowskim od 12 IX 1945 r. Zastapił na tym stanowisku Mariana Lwa. [w:] Encyklopedia katolicka, t. 2, red. F. Gryglewicz, R. Łukaszyk, Z. Sułowski, Lublin 1976, s. 275. 
ale składać pismo do województwa o przydział, a gdy kościoły zostaną przyznane, delegat Kurii poświęci przyznane świątynie. Pismo takie wysłałem o kościoły w Pieckach, Nawiadach, Mikołajkach i Szestnie i czekałem na przydział. Niepokoiło mnie tylko, jak będę się tłumaczył przed Kurią, że dwa kościoły (w Pieckach i Nawiadach) już poświęciłem.

Zimą byłem unieruchomiony, gdyż maruderzy sowieccy zabrali mi konia, gdy za radą wójta w Marcinkowe, razem z furmanami starostwa, wysłałem Mazura Królika po paszę do Karwii ${ }^{35}$.

W lutym [1946 r.] wróciła do Mrągowa jednostka Wojska Polskiego. Powstał komitet przyjęcia, do którego należałem. Komitet urządzał bankiet, na którym byłem jako członek tegoż komitetu. Tam dowiedziałem się od starosty Krzywińskiego ${ }^{36}$, że do powiatu przybędą polscy pastorzy. Przybyło ich dwóch; do Mrągowa [Jan] Szczech ${ }^{37}$, a do Ukty - [Edward] Szendel. Było ich więc trzech w powiecie, a po przybyciu ks. [Władysława] Pilcha do Mikołajek - w sumie czterech, a ja jeden. Przejęli wszystkie kościoły ewangelickie, nawet te, w których odprawiałem [msze]. Na wiosnę w kurii robiono mi zarzuty, że nie przejąłem [wcześniej] kościołów. Kościoły ewangelickie, oprócz Piecek, bo tam już w 1944 r. nie odprawiano [mszy], nie były opuszczone. Ewangelicy odprawiali nabożeństwa bez pastorów. Katolików na wioskach tak jakby nie było. Nie można więc było pozbawiać świątyń ewangelików, byłoby to nieludzkie postępowanie, dla garstki ludności polskiej. Nawet gdybym te kościoły zajął, pastorzy przy poparciu władz państwowych odebraliby je z powrotem, jak stało się w Nawiadach i Pieckach. Pastorzy byli na terenie powiatu popierani, otrzymywali etaty nauczycieli i pensje. Jest to zrozumiałe, ze względu na wielką ilość ewangelików Mazurów, których chciano odzyskać dla Polski. Niestety było już za późno. Poprzednie błędy, jak również i to, że władze niemieckie zgermanizowały lud, który mówiąc gwarą mazurską, nie zdawał sobie sprawy, że jest z pochodzenia polskim ${ }^{38}$. Neofici zawsze są gorliwsi. Ewangelicy niezbyt uczęszczali na nabożeństwa w języku polskim. W Mikołajkach grabarz, który pod nieobecność pastora przewodniczył nabożeństwom swoim, chwalił się, że gdy on odprawia, ma więcej ludzi w kościele. Do wiosny [1946 r.] odprawiałem tylko w mieście. Dopiero w wielkim poście ruszyłem w teren. Objechałem mieszkańców na południu powiatu, a więc w okolicy Nawiad i Piecek, kolędując, odprawiając msze po wioskach, spowiadając. Wyjeżdżałem zwykle na kilka dni, nocując na wioskach.

Wobec zabrania kościołów w Nawiadach i Pieckach, msze święte odprawiałem w szkołach, gdzie nie wszystkie sale były zajęte. W Mikołajkach samych, bo na wioskach była w tym czasie znikoma ilość Polaków. Kolędowałem i spowiadałem

Karwie, niewielka wieś położona obok Mrągowa.

37 Ks. Jan Szczech (ur. 1909), Mazur, duchowny ewangelicki. W 1945 r. współtworzył świecką Radę Kościoła Ewangelickiego w Olsztynie, potem do 1954 r. był pierwszym powojennym administratorem parafii ewangelicko-augsburskiej w Mrągowie, a następnie w Giżycku.

38 Na końcu tego zdania ks. Dudziak w zwykłym nawiasie dopisał: „(por.: M. Wańkowicz, Na tropach Smętka)". Po raz pierwszy książka została wydana w 1936 r. Pierwsze powojenne wydanie: M. Wańkowicz, Na tropach Smętka, Warszawa 1958. 
19 marca. Mszę świętą odprawiłem w kaplicy, która zajmowała połowę dzisiejszej plebanii. W drugiej połowie mieszkał Niemiec - zakrystianin.

W mieście odprawiałem przez zimę w niedzielę trzy msze święte. Pierwszą o 7 [rano] w kaplicy sióstr Misjonarek w sierocińcu ${ }^{39}$, drugą o 9 dla młodzieży i dzieci, a później dla wojska i wreszcie o 11 sumę. 09 godzinie kościół był pełen z chwilą, gdy wojsko przychodziło do kościoła. Dzieci i młodzież przychodziła sama z domów. Nie chciałem wprawdzie przyganiania dzieci w szeregu, gdyż uważałem, że lepiej, gdy dziecko czy młodzieniec nabierze nawyku chodzenia do kościoła bez przymusu zewnętrznego. Pamiętałem bowiem ze swej młodości, że młodzież bywała w kościele, gdy ją przyprowadzono, a w dniach, gdy tego przymusu nie było, mszę świętą opuszczała.

Siostry sprowadziłem jesienią 1945 r. Objęły poniemiecki sierociniec, prowadzony przez diakonisie ewangelickie. Naturalnie nikt dzieci gwałtem nie nawracał. Na mszę dzieci przychodziły i tylko jedna dziewczyna przejęła katolicyzm. Większość [z pozostałych, później] wyjechała do Niemiec.

Przed Wielkanocą dla dzieci urządziłem rekolekcje. Sam je prowadziłem, bo tak z braku komunikacji, jak i z braku funduszów rekolektanta sprowadzić nie mogłem. Sam również spowiadałem. W Wielką Sobotę po południu, za zezwoleniem Kurii odprawiłem drugą mszę świętą w Pieckach w gmachu szkoły. Przed mszą świętą spowiadałem. Rezurekcję pomogli mi urządzić żołnierze. Dowódcą jednostki był przedwojenny oficer, który czas okupacji spędził na Węgrzech, pułkownik [Zygmunt] Semerga. Aby procesja mogła przejść dookoła kościoła, trzeba było spiłować trzy drzewa rosnące na ścieżce. Uczynili to żołnierze. Żołnierze pełnili wartę przy grobie, żołnierze nieśli krzyż, chorągwie i baldachim. Brała udział w procesji też warta honorowa. Reszta pułku wraz z dowódcą przyszli na późniejszą mszę.

W lutym [1946 r.] otrzymałem pismo z PCK $^{40} \mathrm{w}$ Olsztynie, w którym proszono mnie, bym przyczynił się do zorganizowania [filii] tej instytucji w Ządzborku. Porozumiałem się z naczelnikami [Zygmuntem] Wieliczką i Gudeckim i u mnie na plebanii urządziliśmy zebranie organizacyjne. Przyszedł jeszcze kierownik Urzędu Melioracyjnego z żoną i pan Wasilewski z tegoż urzędu. Kierownictwo powierzono mnie. U mnie na plebanii zarząd urządzał zebrania, na których opracowywano plan pracy. Zaczęliśmy werbować członków, zakładać koła w terenie, szczególnie w szkołach, które zaczęły powstawać w terenie, wciągając do współpracy nauczycieli. Nadesłano wkrótce paczki z Czerwonego Krzyża. Przybyli do nas również przedstawiciele szwedzkiego Czerwonego Krzyża ${ }^{41}$. Potrzebny był magazyn. Zanim otrzymaliśmy własny lokal, oddałem do dyspozycji PCK lokal i magazyn w opróżnionym

39 Sierociniec w Mrągowie, usytuowany przy ul. Jeziornej 1, prowadziły wówczas Siostry Misjonarki Św. Rodziny. Jedna z sióstr została później gospodynią ks. Władysława Dudziaka.

40 Olsztyński Oddział Polskiego Czerwonego Krzyża uruchomiono w listopadzie 1945 r. Prócz codziennego wsparcia dla najuboższych przygotowywano też upominki świąteczne.

41 Przedstawiciele Szwedzkiego Czerwonego Krzyża przyjeżdżali do Polski od 1946 r. (głównie do województwa gdańskiego i olsztyńskiego). Przywożono sprzęt medyczny do szpitali i ambulatoriów oraz apteczki. Sprowadzono też pierwsze karetki pogotowia. Dożywiano najuboższych i przygotowywano paczki świąteczne. 
przez dzikich lokatorów domu parafialnym. PCK w Ządzborku kierowałem do czasu, gdy znaleźli się ludzie do pracy w nim i gdy ja sam miałem zbyt dużo pracy.

Na wiosnę bowiem powstał Caritas w Olsztynie ${ }^{42}$ i zaczęto otwierać oddziały po parafiach. Szczęśliwie udało mi się zwerbować do Zarządu rzutkich ludzi. Prezesem był Pan Gajewski, członkami zarządu: mój brat, jego kolega z pracy, nauczyciel Ziemiański i jego żona. Na członków zwerbowaliśmy sporo osób, w tym dr. Lucka, państwa Brudnickich. W aptece była puszka do ofiar na Caritas i często trzeba było ją opróżniać. W maju [1946 r.] otworzyliśmy kuchnię, która wydawała do 500 obiadów dziennie. Na obiad była zupa i chleb. Zupę otrzymywał każdy potrzebujący bez różnicy narodowości i wyznania. Kuchnia była czynna do końca 1947 r. Na święta wielkanocne wydzielaliśmy święcone. Fundusz na to zdobyliśmy, urządzając w kościele koncert religijny. Tak w PCK, jak i w Caritasie wszyscy pracowali bezinteresownie. W pracy caritasowej bardzo pomocna była katechetka, s. Janina Pietkiewicz. Prowadziła magazyn i księgę inwentarzową i magazynową.

W 1947 r. powstał internat dla niezamożnej młodzieży męskiej. Doszła mi wówczas jeszcze funkcja kierownika i wychowawcy internatu. Opłaty w internacie były niższe niż w państwowych [instytucjach tego typu], a niektórzy chłopcy nie płacili nic. Internat prowadziliśmy do 1950 r. Po raz pierwszy obchodzono na tej ziemi [rocznice uchwalenia Konstytucji] 3 maja $^{43}$. Szkoły miały wolne dni od nauki, 1, 2, 3 maja. Pierwszego maja odprawiłem mszę świętą. Były na mszy dzieci, młodzież i wychowawcy. Również 3 maja był ten sam porządek. Inspektorat postarał się dla naszego gimnazjum o samochód ciężarowy i udaliśmy się do Mikołajek, gdzie młodzież miała przeprowadzić zbiórkę do puszek. W kaplicy odprawiłem mszę świętą. Wzięła w niej udział nasza młodzież i społeczeństwo z Mikołajek. Po mszy świętej młodzież z wychowawczynią przeprowadziła zbiórkę i po obiedzie powróciliśmy do Ządzborka.

Jeszcze raz, wiosną [1946 r.] odprawiłem [mszę] w Mikołajkach. Dojechałem tam własnym koniem. Innej komunikacji nie było ${ }^{44}$. Dojeżdżałem też do Piecek i Nawiad. W Zielone Święta przyjechał ks. [Józef] Chomski ${ }^{45}$. Zatrzymał się u mnie i szukał dla siebie placówki. Namówiłem go, by osiadł w Ządzborku. Nie zgodził się, chciał mieć własny kościół. Wysłałem więc delegację do pastora Szendla ${ }^{46}$, później sam

42 Dzięki staraniom Caritasu powstała darmowa kuchnia dla najuboższych. Siedziba organizacji mieściła się nieopodal plebanii św. Wojciecha.

43 W tym miejscu Autor wspomina rok 1946.

44 W lipcu 1945 r. w jednym z protokołów inspekcji starostwa w Mrągowie napisano, że miasto jest „odcięte od świata" z powodu rozebranych przez Rosjan torów kolejowych. Linię kolejową, łączącą Olsztyn, Mrągowo i Mikołajki, uruchomiono dopiero 7 X 1946 r.

45 Ks. Józef Chomski (1897-1966) na Warmię przybył z Wileńszczyzny wiosną 1946 r. Zamieszkał na plebanii u ks. Władysława Dudziaka. Początkowo dojeżdżał do Mikołajek, gdzie w kaplicy co niedzielę odprawiał msze św. Potem, od 4 VII 1946 r. proboszcz w Pieckach; A. Kopiczko, Józef Chomski [biogram], [w:] Duchowieństwo katolickie..., s. 42, zob.: http://parafiapiecki.pl/historia/kronika-parafialna/_(dostęp: 23 V 2018 r.).

46 Ks. Edward Szendel, pastor ewangelicki, pastor w Ukcie, wsi w powiecie mrągowskim, E. Kruk, op. cit. 
pojechałem i pastor Szendel zgodził się odstąpić kościół w Pieckach [katolikom]. Od lipca [1946 r.] odpadły mi okolice Piecek i Nawiady - najbardziej zasiedlone wioski. Miałem teraz do obsługi Ządzbork i Mikołajki.

9 maja [1946 r.] w rocznicę zakończenia wojny odprawiłem polową mszę świętą, z trybuny obejrzałem defiladę i byłem na obiedzie żołnierskim. Wojsko pomagało mi urządzić procesję Bożego Ciała. PKS z Olsztyna uruchomił komunikację odpowiednio dostosowanymi ciężarowymi samochodami z Olsztyna do Mikołajek i z powrotem. Chodziły niezbyt punktualnie. Na okres letni trzeba było każdej niedzieli być w Mikołajkach, by obsłużyć nie tę nieliczną garstkę osadników, ale turystów, harcerzy, studentów.

Z Kurii otrzymałem polecenie obsłużenia obozu studentów w Sorkwitach. Dwie msze święte w Ządzborku, jedna w Mikołajkach i jedna w obozie w Sorkwitach, to było za wiele na mnie jednego, choć jeszcze młodego. Na szczęście jezuita o. [Piotr] Burzak (obecnie [w 1974 r.] w Brazylii czy Argentynie ${ }^{47}$ ) musiał usunąć się ze Świętej Lipki. Osiadł w sierocińcu u sióstr i zgodził się w niedzielę obsługiwać Mikołajki. Mogłem więc podołać pracy dzięki pomocy o. Burzaka. Tylko jedną niedzielę musiałem wszystko sam zrobić.

Po mszy w Ządzborku, o 9 rano pojechałem do Mikołajek [31 km]. Z Mikołajek wozem pocztowym przez Ryn wróciłem do Mrągowa [40 km] i po południu na szóstą motocyklem zabrali mnie studenci do Sorkwit [11 km]. Tam po mszy świętej zjadłem pierwszy i ostatni zarazem tego dnia posiłek. Jednej niedzieli studenci urządzili ognisko, na którym był obecny wojewoda olsztyński. W rozmowie ze mną obiecał, że gdy Niemcy z Mikołajek wyjadą, kościół zostanie przekazany katolikom, a ewangelicy otrzymają katolicką kaplicę. Wojewoda i czasy zmieniły się i obietnica nie została spełniona ${ }^{48}$.

Obok stała kaplica jakiejś sekty protestanckiej, która w czasie działań [wojennych] służyła za stajnię, o czym świadczył nawóz. Powołałem komitet, ponieważ sam mogłem być tam tylko w niedzielę i zajęliśmy tę kaplicę, oczyściliśmy [ją] i wyremontowaliśmy. Koszta wyniosły 50 tys. zł. Katolicy się opodatkowali, a ja oddałem z opłat za posługi z terenu, który miał należeć do Mikołajek. Po przeciwnej ulicy zajęliśmy część domu na plebanię, wyremontowaliśmy i częściowo umeblowaliśmy. Zatrudniłem katechetkę panią Kurułkową, która zamieszkała w wyremontowanej plebanii. Kaplicę zaopatrzyłem w szaty i naczynia liturgiczne. Placówka była gotowa na przyjęcie kapłana na stałe i od września 1948 r. Kuria Biskupia delegowała do Mikołajek ks. Jana Latochę ${ }^{49}$. Gdy robiono remont w kaplicy w Mikołajkach,

47 Jezuita o. Piotr Burzak w latach 50. XX w. był misjonarzem w Brazylii. Por.: Encyklopedia wiedzy o jezuitach na ziemiach Polski i Litwy 1564-1995, Kraków 1996, s. 79.

48 Ks. Władysław Dudziak rozmawiał z wojewodą dr. Zygmuntem Roblem (1891-1976), który pełnił tę funkcję od 15 XII 1945 r. do 8 IX 1947 r. Jego następcą był Wiktor Jaśkiewicz.

49 Przystosowano zdewastowany Dom Ludowy na potrzeby katolickiego kultu religijnego. Remont ukończono po ok. 3 miesiącach (m.in. powiększono wówczas kościół, przeznaczając na ten cel fragment przylegającego prywatnego mieszkania). Za zgodą Kurii Biskupiej aktu poświęcenia dokonał ks. Władysław Dudziak. 
w tym czasie przeprowadzono remont wieży i dachu kościoła w Mrągowie, bo tak od 1947 r. nazywał się Ządzbork ${ }^{50}$. O tyle wzrosła już liczba parafian, że mogłem pokusić się o przeprowadzenie remontu. W mieście powstała spółdzielnia „Odbudowa"51. Ona to zgłosiła się do roboty. Kosztorys na remont wieży dachu kościoła opiewał na 299 tys. zł. Wydał mi się wygórowany. Rada parafian jednak uznała, że nie jest zawyżony. Okazało się jednak, że ja miałem rację, a nie członkowie Rady. Ustawiono rusztowania i przystąpiono do roboty. Robota trwała całe lato. Materiał do remontu był poniemiecki. Musiało coś do niego dostać się niewłaściwego, gdyż zimowa porą słupki na wierzchu wieży zaczęły się rozpadać i groziły runięciem. Zagrażało to bezpieczeństwu. Zarządziłem rozebranie słupków podczas zimy. Majster z firmy, zdun, autochton, którego synowie mieli wejść na wieżę i rozebrać słupki, zagroził spółdzielni, że jeżeli synom stanie się nieszczęście, to on odbierze sobie życie. Operacja rozebrania udała się szczęśliwie. W 1948 r. poprawiono remont. Tym razem materiał kupiłem sam, by znów nie spartolono [roboty]. Ponieważ spółdzielnia właściwie nie miała czym opłacić robotników, zapłaciłem sam. W tym roku brat mój Józef - stolarz, dorobił ramy do okien wieży, oszklił je i dorobił żaluzje do okien wieży dzwonnicy. Jednocześnie Masny Wł. zrobił ogrodzenie od ulicy Czerwonej Armii. Całość robót kosztowała do 400 tys. zł. 


\section{Bibliografia}

Bielawny K., Kościół ewangelicko-augsburski na Warmii i Mazurach po II wojnie światowej w spojrzeniu historyczno-ekumenicznym, Olsztyn 2008.

Bielawny K., Parafia katolicka w Mragowie od XV do 1. połowy XX wieku, „Studia Elbląskie”, nr 7 (2006), s. 53-67.

Bielawny K., Przejmowanie Kościołów ewangelickich przez ludność katolickq na terenie diecezji warmińskiej w latach 1945-1946, „Forum Teologiczne”, nr 8 (2007), s. 111-120.

Encyklopedia wiedzy o jezuitach na ziemiach Polski i Litwy 1564-1995, Kraków 1996.

Gołębiowski B., rec. Z pogranicza kurpiowsko-mazurskiego: 1945-1957, „Kultura i Społeczeństwo”, nr 38 (1/1994), s. 227-228.

Kopiczko A., Duchowieństwo katolickie diecezji warmińskiej w latach 1945-1992, Słownik, cz. 2, Olsztyn 2007.

Kopiczko A., Dzieje kościoła i parafii św. Wojciecha w Mragowie do 1945 r., Olsztyn 2015.

Kopiczko A., Józef Chomski [biogram], [w:] Duchowieństwo katolickie Diecezji Warmińskiej w latach 1945-1992, cz. 2: Słownik, Olsztyn 2007, s. 42.

Kopiczko A., Stanisław Kobyłecki [biogram], [w:] Duchowieństwo katolickie Diecezji Warmińskiej w latach 1945-1992, cz. 2: Słownik, Olsztyn 2007, s. 136.

Kruk E., Księża Diecezji Mazurskiej Kościoła Ewangelicko-Augsburskiego w Polsce w latach 1945-1950, „Biuletyn Mazurskiego Towarzystwa Ewangelickiego w Olsztynie”, nr 7 (2007), http://diec.mazurska. luteranie.pl/pl/biuletyn/MTE_2007_07_49.htm\#JaguckiA (dostęp: 28 V 2018 r.).

Murawska H., Ludność z polskich Kresów Wschodnich w powiecie mrq̨gowskim, „Mrągowskie Studia Humanistyczne", nr 1 (1999), s. 89-102.

Sakson A., Mazurzy - społeczność pogranicza, Poznań 1990.

Sopuch K., W. Dudziak, Z pogranicza kurpiowsko-mazurskiego: 1945-1957, Ostrołęka 1993.

Szorc A., Teodor Bensch (1903-1958), Encyklopedia katolicka, red. F. Gryglewicz, R. Łukaszyk, Z. Sułowski, t. 2, Lublin 1976.

Tomkiewicz R., Mragowo w latach 1945-1947, „Mrągowskie Studia Humanistyczne”, nr 1 (1999), s. 69-88. 


\section{Władysław Dudziak, Wspomnienia z lat 1945-1948}

Streszczenie: Ks. Władysław Dudziak przybył do Mrągowa wiosną 1945 r. wraz z jedną z grup przesiedleńców z północnego Mazowsza. W mieście nie było wówczas żadnego kapłana, dom parafialny był wypalony, bez okien, rozkradziony i zdewastowany. Pisząc o życiu parafialnym, wiele informacji dotyczy też ówczesnej, mrągowskiej codzienności. Ks. Dudziak uczestniczył np. w organizacji mrągowskiego gimnazjum, w którym następnie prócz religii uczył też matematyki. Prowadził internat. W miasteczku proboszczem był do 1960 r. We wspomnieniach ks. Dudziaka, przywołujących powojenną codzienność, przeważa optymizm i wiara w odbudowę życia społecznego.

\section{Władysław Dudziak, Recollections from the years 1945-1948}

Abstract: Father Władysław Dudziak arrived in Mragowo in spring 1945 along with one of the groups of resettlers from northern Mazowsze. At the time the town did not have a priest, and the church hall was burnt out and windowless, had been looted and was a complete ruin. Writing about parish life, much of the information Father Dudziak includes concerns daily life in Mrągowo at that time. Father Dudziak played a role in the establishment of the high school in Mrągowo where - apart from religious studies - he also taught mathematics. He also ran the school boarding house. He was parish priest in the town until 1960. In Father Dudziak's recollections, which recall postwar daily life, optimism and belief in the rebuilding of social life predominate.

Słowa kluczowe: Mragowo, organizacja życia religijnego, relacje osadników z ludnością autochtoniczną

Keywords: Mragowo, organisation of religious life, relations between settlers and local people 